\title{
Microsatellite instability and cytogenetic survey in myeloid leukemias
}

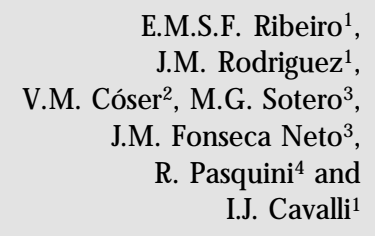

E.M.S.F. Ribeiro ${ }^{1}$

J.M. Rodriguez ${ }^{1}$, V.M. Cóser ${ }^{2}$, M.G. Sotero ${ }^{3}$, J.M. Fonseca Neto ${ }^{3}$,

R. Pasquini ${ }^{4}$ and

I.J. Cavalli ${ }^{1}$

\author{
1Departamento de Genética, Universidade Federal do Paraná, Curitiba, PR, Brasil \\ ${ }^{2}$ Departamento de Hematologia-O ncologia, Hospital Universitário de Santa Maria, \\ Santa Maria, RS, Brasil \\ ${ }^{3} \mathrm{H}$ emocentro de Pernambuco, Recife, PE, Brasil \\ ${ }^{4}$ Unidade de Transplante de Medula Ó ssea, Hospital de Clínicas, \\ Universidade Federal do Paraná, Curitiba, PR, Brasil
}

\section{Correspondence \\ E.M.S.F. Ribeiro \\ Departamento de Genética, UFPR \\ Caixa Postal 19071 \\ 81531-970 Curitiba, PR \\ Brasil \\ Fax: + 55-41-266-2042 \\ E-mail: eribeiro@bio.ufpr.br}

Research partially supported by CNPq.

Received March 8, 2001

Accepted November 7, 2001

\section{Abstract}

Microsatellites are short tandem repeat sequences dispersed throughout the genome. Their instability at multiple genetic loci may result from mismatch repair errors and it occurs in hereditary nonpolyposis colorectal cancer. This instability is also found in many sporadic cancers. In order to evaluate the importance of this process in myeloid leukemias, we studied five loci in different chromosomes of 43 patients, 22 with chronic myelocytic leukemia (CML) in the chronic phase, 7 with CML in blast crisis, and 14 with acute myeloid leukemia (AML), by comparing leukemic DNA extracted from bone marrow and constitutional DNA obtained from buccal epithelial cells. Only one of the 43 patients (2.1\%), with relapsed AML, showed an alteration in the allele length at a single locus. Cytogenetic analysis was performed in order to improve the characterization of leukemic subtypes and to determine if specific chromosome aberrations were associated with the presence of microsatellite instability. Several chromosome aberrations were observed, most of them detected at diagnosis and during follow-up of the patients, according to current literature. These findings suggest that microsatellite instability is an infrequent genetic event in myeloid leukemias, adding support to the current view that the mechanisms of genomic instability in solid tumors differ from those observed in leukemias, where specific chromosome aberrations seem to play a major role.

\section{Introduction}

Microsatellite instability (MSI) constitutes a recognized mechanism of mutation involved in human cancer. Differences in nucleotide repeats, representing either an expansion or a reduction of these sequences, were initially described in hereditary nonpolyposis colorectal cancer (HNPCC) (1)

\section{Key words} - Genomic instability

- Mismatch repair errors

- Cytogenetics

- Leukemogenesis 
al. (5) reported a high frequency (53\%) of MSI in the evolution of chronic myelocytic leukemia (CML) from chronic phase to blast crisis and concluded that this loss of fidelity in replication and repair mechanism may be associated with CML evolution. However, other studies have shown that instability is infrequent in the evolution of CML to blast crisis $(6,7)$ and in acute leukemias (8-12). On the other hand, cytogenetic analysis is of recognized importance in leukemias since the years before the availability of banding techniques, but few studies have discussed both mechanisms together. We report here a study of MSI and cytogenetics in 43 patients with different types of myeloid leukemias.

\section{Material and Methods}

\section{Clinical samples}

Bone marrow samples were obtained from 36 untreated patients, 22 with CML in the chronic phase and 14 with acute myeloid leukemia (AML), and from 7 patients with CML in blast crisis previously treated for the chronic phase. Thirty samples were collected at the Department of Hematology, University Hospital, Federal University of Paraná (UFPR), Curitiba, PR, 10 were collected at the Department of Hematology-Oncology, University Hospital, Santa Maria, RS, both in South of Brazil, and 3 were collected at the Blood Center of Recife, PE, Northeast Brazil. The samples were collected in 1996 and 1997. During this period, all patients whose bone marrow samples were sent to the Cytogenetics Unit (UFPR) were considered. On the occasion of the next ambulatory visit of the patient, following approval by the referring physician, informed consent was obtained and buccal epithelial cells were collected as a source of constitutional DNA. For the patients admitted to the hospital, consent was obtained on the ward. The study was approved by the Hospital Ethics Committee (UFPR).
Samples for which it was not possible to obtain amplification products of a minimum of two loci were excluded from the study (two from patients with blast crisis and one from a patient with AML). We believe that, within the defined period of time for sample collection from patients referred to the Hematology Department, the data were fully randomized, without any bias. At the other two centers where samples were obtained the same selection criteria were used. Fifteen cases were received from the Blood Center of Pernambuco; however, only three cases were feasible for DNA extraction.

The types of leukemias were diagnosed according to the French-American-British (FAB) classification (13) using immunohistochemistry, immunophenotyping and cytogenetics.

\section{Cytogenetic analysis}

Bone marrow aspirates were processed by the method of Williams et al. (14), G banding was performed by the method of Scheres (15), and karyotypes were described according to the International System for Human Cytogenetic Nomenclature (16).

\section{DNA isolation}

Genomic DNA from bone marrow samples and buccal epithelial cells was obtained by phenol-chloroform extraction following proteinase $\mathrm{K}$ treatment, as previously described (17).

\section{Microsatellite amplification}

Polymerase chain reactions (PCR) were performed on $50 \mu \mathrm{l}$ of reaction mixture containing $50 \mathrm{mM} \mathrm{KCl}, 2.0 \mathrm{mM} \mathrm{MgCl} 2,10 \mathrm{mM}$ Tris, $\mathrm{pH} 8.3,200 \mu \mathrm{M}$ of each of the four dNTPs, $0.25 \mu \mathrm{M}$ of each primer, $12.5-50 \mathrm{ng}$ of genomic DNA, and $2.5 \mathrm{U}$ of Taq polymerase (Gibco-BRL, Gaithersburg, MD, USA). Samples were processed through 28 
cycles at $94^{\circ} \mathrm{C}$ for $30 \mathrm{~s}, 62^{\circ} \mathrm{C}$ for $30 \mathrm{~s}$ and $72^{\circ} \mathrm{C}$ for 2 min in a Perkin Elmer/Cetus thermal cycler 9600 (Norwalk, CT, USA).

\section{Single-strand conformation polymorphism}

Amplified PCR fragments were diluted 1:1 in denaturing loading buffer consisting of $98 \%$ formamide, $10 \mathrm{mM}$ EDTA, $\mathrm{pH} 8.0$, $0.02 \%$ bromophenol blue, and $0.02 \%$ xylene cyanol $\mathrm{FF}$, and denatured at $94^{\circ} \mathrm{C}$ for $5 \mathrm{~min}$. The denatured and non-denatured reactions were subjected to electrophoresis side by side in a vertical discontinuous polyacrylamide gel system (18). A non-denatured sample was used to control for the presence of technical artifacts, which could lead to the false conclusion of the presence of new alleles. Electrophoresis was run overnight at 10 $\mathrm{W}$ (room temperature) and bands were detected by silver staining (19).

\section{Analysis of microsatellite instability}

We examined the extracted DNA for genetic alterations at five separate loci containing nucleotide repeat sequences. Information on repeat sequences, chromosome localization, length of amplified fragments and primer sequences, obtained from the $\mathrm{Ge}$ nome Database (20), are indicated in Table 1. MSI was analyzed by comparison of DNAbanding patterns of PCR products of micro- satellite sequences in leukemic and matched normal buccal epithelial cells.

\section{Statistical analysis}

The detection of MSI as a function of the number of analyzed loci was evaluated by the regression coefficient.

\section{Results and Discussion}

Alterations in microsatellite markers have been implicated as a frequent feature in HNPCC (75-78\%) (1) and in some sporadic cancer $(3-30 \%)(2,3)$. The data for leukemias are contradictory, ranging from zero to 94\% in different reports (5-12,21-32). Here we report a study on 43 patients with CML and AML. Patients' characteristics are described in Table 2. Of 207 paired PCR reactions, 178 were informative $(86 \%)$. In the other 29 samples, amplification failed or DNA was not sufficient. Only one patient with relapsed AML showed instability at a single locus $(2.3 \%)$ as indicated in Table 2 and Figure 1.

Most reports did not show instability during the chronic phase of CML $(5-7,9,21)$ and our results agree with them. Although the instability of microsatellites is implicated in the evolution from chronic phase to blast crisis (5), other authors $(6,7)$ have not confirmed these results, and the present report is

Table 1. Synthetic oligonucleotides used in this study.

\begin{tabular}{|c|c|c|c|c|}
\hline Marker & $\begin{array}{l}\text { Chromosomal } \\
\text { location }\end{array}$ & $\begin{array}{l}\text { Amplicon size } \\
\text { range (bp) }\end{array}$ & $\begin{array}{l}\text { Core repeat } \\
\text { unit }\end{array}$ & $\begin{array}{l}\text { Nucleotide sequence } \\
\text { of primers }\left(5^{\prime}-3^{\prime}\right)\end{array}$ \\
\hline TPO & $2 p 25-2 p 24$ & $106-330$ & AATG & $\begin{array}{l}\text { CACTAGCACCCAGAACCGTC } \\
\text { CCTTGTCAGCGTTTATTTGCC }\end{array}$ \\
\hline TH01 (TC11) & $11 p 15.5$ & 179-199 & CATT & $\begin{array}{l}\text { GTGATTCCCATTGGCCTGTTCCTC } \\
\text { GTGGGCTGAAAAGCTCCCGATTAT }\end{array}$ \\
\hline ARA & Xq11.2-Xq12 & 263-305 & AGC & $\begin{array}{l}\text { GCTGTGAAGGTTGCTGTTCCTCAT } \\
\text { TCCAGAATCTGTITCAGAGCGTGC }\end{array}$ \\
\hline SE33 (ACTPB2) & $6 q 13$ & $229-337$ & AAAG & $\begin{array}{l}\text { AATCTGGGCGACAAGAGTGA } \\
\text { АСATCTCCCCTACCGCTATA }\end{array}$ \\
\hline FES & $15 q 26.1$ & $208-228$ & ATTा & $\begin{array}{l}\text { GGGATTTCCCTATGGATTGG } \\
\text { GCGAAAGAATGAGACTACAT }\end{array}$ \\
\hline
\end{tabular}


Table 2. Patient characteristics, microsatellite instability, cytogenetic analysis and follow-up.

\begin{tabular}{|c|c|c|c|c|c|c|c|c|c|}
\hline \multirow{2}{*}{$\begin{array}{l}\text { Patient } \\
\text { number }\end{array}$} & \multirow[t]{2}{*}{ Sex/Age } & \multirow{2}{*}{$\begin{array}{l}\text { Type of leukemia } \\
\text { (FAB classification) }\end{array}$} & \multicolumn{5}{|c|}{ Microsatellites } & \multirow[t]{2}{*}{ Partial karyotype } & \multirow[t]{2}{*}{ Follow-up } \\
\hline & & & TPO & TH01 & ARA & SE33 & FES/FPS & & \\
\hline 1 & $F / 28$ & CML-CP & $(-)$ & $(-)$ & $(-)$ & $(-)$ & $(-)$ & $\mathrm{t}(9 ; 22)(q 34 ; q 11)$ & Allogeneic BMT \\
\hline 2 & $M / 34$ & CML-CP & $(-)$ & $(-)$ & $(-)$ & $(-)$ & $(-)$ & $\mathrm{t}(9 ; 22)(q 34 ; q 11)$ & $\mathrm{Ct}$ \\
\hline 3 & M/39 & CML-CP & $(-)$ & $(-)$ & $(-)$ & $(-)$ & $(-)$ & $\mathrm{t}(9 ; 22)(q 34 ; q 11)$ & Allogeneic BMT \\
\hline 4 & $M / 38$ & CML-CP & $(-)$ & $(-)$ & $(-)$ & $(-)$ & $(-)$ & $\mathrm{t}(9 ; 22)(\mathrm{q} 34 ; \mathrm{q} 11)$ & Allogeneic BMT \\
\hline 5 & $\mathrm{M} / 60$ & CML-CP & $(-)$ & $(-)$ & $\mathrm{F}$ & ND & ND & $\mathrm{t}(9 ; 22)(q 34 ; q 11)$ & Blast crisis \\
\hline 6 & $M / 23$ & CML-CP & $(-)$ & $(-)$ & $(-)$ & $(-)$ & $\mathrm{F}$ & $\mathrm{t}(9 ; 22)(q 34 ; q 11)$ & $\mathrm{Ct}$ \\
\hline 7 & $\mathrm{M} / 31$ & CML-CP & $(-)$ & $(-)$ & $(-)$ & $(-)$ & $(-)$ & $\mathrm{t}(9 ; 22)(q 34 ; q 11)$ & $\mathrm{Ct}$ \\
\hline 8 & $M / 25$ & CML-CP & $(-)$ & $(-)$ & $(-)$ & $(-)$ & $(-)$ & $\mathrm{t}(9 ; 22)(q 34 ; q 11)$ & Allogeneic BMT \\
\hline 9 & $\mathrm{~F} / 66$ & CML-CP & $(-)$ & $(-)$ & $(-)$ & $(-)$ & $(-)$ & $\mathrm{t}(9 ; 22)(\mathrm{q} 34 ; \mathrm{q} 11)$ & Blast crisis - death \\
\hline 10 & $M / 5.9$ & CML-CP & $(-)$ & $(-)$ & $(-)$ & $(-)$ & $\mathrm{F}$ & $\mathrm{t}(9 ; 22)(q 34 ; q 11)$ & $\mathrm{Ct}$ \\
\hline 11 & $\mathrm{M} / 47$ & CML-CP & $(-)$ & $(-)$ & $(-)$ & $(-)$ & $(-)$ & $\mathrm{t}(9 ; 22)(q 34 ; q 11)$ & $\mathrm{Ct}$ \\
\hline 12 & $F / 29$ & CML-CP & $(-)$ & $(-)$ & $(-)$ & $(-)$ & $\mathrm{F}$ & $\mathrm{t}(9 ; 22)(q 34 ; q 11)$ & $\mathrm{Ct}$ \\
\hline 13 & $M / 53$ & CML-CP & $(-)$ & $(-)$ & $\mathrm{F}$ & $\mathrm{F}$ & $\mathrm{F}$ & $\mathrm{t}(9 ; 22)(q 34 ; q 11)$ & $\mathrm{Ct}$ \\
\hline 14 & $\mathrm{M} / 42$ & CML-CP & $(-)$ & $(-)$ & $(-)$ & $(-)$ & $(-)$ & $t(9 ; 22)(q 34 ; q 11)$ & Death \\
\hline 15 & $F / 30$ & CML-CP & $(-)$ & $(-)$ & $(-)$ & $\mathrm{F}$ & ND & $\mathrm{t}(9 ; 22)(q 34 ; q 11)$ & $?$ \\
\hline 16 & $\mathrm{~F} / 1.8$ & CML-CP & $(-)$ & $(-)$ & $(-)$ & $(-)$ & $(-)$ & $\mathrm{t}(9 ; 22)(q 34 ; q 11)$ & $?$ \\
\hline 17 & $\mathrm{M} / 55$ & CML-CP & $(-)$ & $(-)$ & $\mathrm{F}$ & $\mathrm{F}$ & ND & $\mathrm{t}(9 ; 22)(q 34 ; q 11)$ & $?$ \\
\hline 18 & $M / 63$ & CML-CP & $(-)$ & $(-)$ & $\mathrm{F}$ & ND & ND & $\mathrm{t}(9 ; 22)(q 34 ; q 11)$ & Accelerated phase \\
\hline 19 & $M / 64$ & CML-CP & $(-)$ & $(-)$ & $(-)$ & $(-)$ & ND & $\mathrm{t}(9 ; 22)(q 34 ; q 11)$ & $\mathrm{Ct}$ \\
\hline 20 & $M / 32$ & CML-CP & $(-)$ & $(-)$ & $(-)$ & $(-)$ & $(-)$ & $\mathrm{t}(9 ; 22)(q 34 ; q 11)$ & Allogeneic BMT \\
\hline 21 & $M / 44$ & CML-CP & $(-)$ & $\mathrm{F}$ & $(-)$ & $(-)$ & $(-)$ & $\mathrm{t}(9 ; 22)(q 34 ; q 11)$ & Accelerated phase \\
\hline 22 & $\mathrm{M} / 30$ & CML-CP & $(-)$ & $(-)$ & $\mathrm{F}$ & $\mathrm{F}$ & $\mathrm{F}$ & $\mathrm{t}(9 ; 22) /+8, \mathrm{t}(9 ; 22)(\mathrm{q} 34 ; \mathrm{q} 11)$ & Accelerated phase-BMT \\
\hline 23 & $M / 31$ & CML-BC & $(-)$ & $(-)$ & $(-)$ & $(-)$ & $(-)$ & ND & Blast crisis - death \\
\hline 24 & $M / 15$ & CML-BC & $(-)$ & $(-)$ & $\mathrm{F}$ & $\mathrm{F}$ & ND & ND & Death \\
\hline 25 & $\mathrm{M} / 20$ & CML-BC & $(-)$ & $(-)$ & $(-)$ & $(-)$ & $(-)$ & $\mathrm{t}(9 ; 22)(\mathrm{q} 34 ; \mathrm{q} 11) /$ idem,-7/idem,-8 & $?$ \\
\hline 26 & $M / 47$ & CML-BC & $(-)$ & $(-)$ & $(-)$ & $(-)$ & $(-)$ & $\mathrm{t}(9 ; 22) /$ idem, $+8,+\operatorname{der}(22) \mathrm{t}(9 ; 22)$ & Blast crisis - death \\
\hline 27 & $\mathrm{~F} / 12$ & CML-BC & $(-)$ & $\mathrm{F}$ & $\mathrm{F}$ & $(-)$ & $(-)$ & $\begin{array}{l}(9 ; 22)(q 34 ; q 11) / \text { idem, } \\
+\operatorname{der}(22) t(9 ; 22)\end{array}$ & $?$ \\
\hline 28 & $\mathrm{M} / 21$ & CML-BC & $(-)$ & $(-)$ & $(-)$ & $(-)$ & $(-)$ & ND & $\mathrm{Ct}$ \\
\hline 29 & $M / 32$ & CML-BC & $(-)$ & $(-)$ & $(-)$ & $(-)$ & $\mathrm{F}$ & $\begin{array}{l}+8, t(9 ; 22)(q 34 ; q 11),+19 \\
+\operatorname{der}(22) t(9 ; 22)\end{array}$ & Death \\
\hline 30 & $M / 57$ & AML-M5b-Relapse & $(-)$ & $(-)$ & $(-)$ & $(+)$ & $\mathrm{F}$ & ND & Death \\
\hline 31 & $\mathrm{~F} / 9.10$ & AML-M3 & $(-)$ & $(-)$ & $(-)$ & $(-)$ & $(-)$ & $\mathrm{t}(15 ; 17)(\mathrm{q} 22 ; \mathrm{q} 11)$ & Death \\
\hline 32 & $\mathrm{~F} / 11$ & ALL L1 - pre-B & $(-)$ & $(-)$ & $(-)$ & $(-)$ & $(-)$ & $\mathrm{t}(1 ; 19)(q 23 ; p 13), \operatorname{del}(15)(q 22)$ & Relapse - Ct \\
\hline 33 & $\mathrm{M} / 21$ & ALL L1 - B & $(-)$ & $(-)$ & $(-)$ & $(-)$ & $\mathrm{F}$ & +21 & Death \\
\hline 34 & $\mathrm{M} / 14$ & AML-M2 & $(-)$ & $(-)$ & $(-)$ & $(-)$ & $(-)$ & +8 & Relapse - Ct \\
\hline 35 & $M / 35$ & ALL pre-B & $(-)$ & $(-)$ & $(-)$ & $(-)$ & $(-)$ & $46, X Y$ & Death \\
\hline 36 & $M / 16$ & ALL L1 - T & $(-)$ & $(-)$ & $(-)$ & $(-)$ & $(-)$ & ND & Death \\
\hline 37 & $F / 20$ & AML-M3 & $(-)$ & $(-)$ & $\mathrm{F}$ & $(-)$ & $\mathrm{F}$ & ND & Death \\
\hline 38 & $F / 35$ & AML-M3 & $(-)$ & $(-)$ & $\mathrm{F}$ & $(-)$ & $\mathrm{F}$ & $\mathrm{t}(15 ; 17)(q 22 ; q 11)$ & Autologous BMT \\
\hline 39 & $F / 39$ & AML-M4 & $(-)$ & $(-)$ & $\mathrm{F}$ & $(-)$ & $(-)$ & $\mathrm{t}(17 ; 19)(\mathrm{q} 22 ; \mathrm{p} 13)$ & Death \\
\hline 40 & $\mathrm{M} / 41$ & AML post-MDS & $(-)$ & $(-)$ & $(-)$ & $(-)$ & $(-)$ & $-7,+$ mar & Death \\
\hline 41 & $\mathrm{M} / 28$ & AML-MO & $(-)$ & $(-)$ & $(-)$ & $(-)$ & $(-)$ & del(5)(p13) & Autologous BMT \\
\hline 42 & $M / 8.6$ & AML-M2 & $(-)$ & $(-)$ & $(-)$ & $(-)$ & $(-)$ & $\mathrm{t}(9 ; 11)(q 22 ; q 23)$ & Death \\
\hline 43 & $M / 16$ & ALL L1 - pre-B & $(-)$ & $(-)$ & $(-)$ & $(-)$ & $\mathrm{F}$ & tmar & Allogeneic BMT \\
\hline 44 & $F / 53$ & AML-M4 & $(-)$ & $(-)$ & $(-)$ & $(-)$ & $(-)$ & $46, X X$ & Relapse - death \\
\hline 45 & $\mathrm{~F} / 59$ & AML & $(-)$ & $(-)$ & $(-)$ & $(-)$ & $(-)$ & $46, X X$ & Death \\
\hline 46 & $\mathrm{~F} / 15$ & AML-M2 & $\mathrm{F}$ & $(-)$ & $(-)$ & $\mathrm{F}$ & $\mathrm{F}$ & $\begin{array}{l}+5,+8, t(8 ; 21)(q 22 ; q 22),+9,-17 \\
+\operatorname{der}(21) t(8 ; 21)\end{array}$ & Death \\
\hline 47 & $\mathrm{~F} / 72$ & AML post-MDS & $(-)$ & $(-)$ & $\mathrm{F}$ & $\mathrm{F}$ & ND & ND & Death \\
\hline 48 & $F / 35$ & AML-M4 & $(-)$ & $(-)$ & $(-)$ & $(-)$ & $(-)$ & $\operatorname{del}(7)(q 32),+m a r$ & Allogeneic BMT \\
\hline
\end{tabular}

$(-)=$ no microsatellite instability, $(+)=$ microsatellite instability, $\mathrm{F}=$ failure in amplification, $\mathrm{ND}=$ not done, $\mathrm{CML}=$ chronic myeloid leukemia, $\mathrm{CP}=$ chronic phase, $\mathrm{BC}=$ blast crisis, $\mathrm{AML}=$ acute myeloid leukemia, $\mathrm{ALL}=$ acute lymphocytic leukemia $\mathrm{Ct}=$ chemotherapy, $\mathrm{BMT}=$ bone marrow transplantation. 
in the same direction, since no alterations in electrophoresis pattern were observed among 7 patients. With respect to the patients with acute leukemias, we studied 14 patients with AML (10 de novo, 1 relapse, 1 secondary to previous acute lymphoblastic leukemia and 2 post-myelodysplastic syndrome). The only case with alteration in the allele length at a single locus (SE33) was the patient in relapse (patient number 30) (7.14\%). Tasaka et al. (10) studied the progression of AML and found $12 \%$ MSI in the diagnostic and remission phase in contrast to $35 \%$ in the relapsed phase, indicating that mismatch repair errors might be of importance during the progression of the disease. Ben-Yehuda et al. (23) found the highest index described (94\%) in patients with therapy-related AML, suggesting a mutator phenotype. Another study, however, concluded that MSI is infrequent in myeloid leukemias. Boyer et al. (11) investigated MSI in the transformation of myeloid cells to myelodysplastic syndrome and/or AML using a panel of 14 microsatellite loci. Only one example of MSI was found in 48 patients. Rimsza et al. (12) retrospectively studied 132 AML cases in adult patients and no single case of MSI was demonstrated either in diagnosted or relapsed cases. Sill et al. (24) studied 20 patients using a panel of 12 microsatellite loci and detected no alterations.

In view of that we analyzed a small number of markers, we checked if this factor could be responsible for the absence of instability in our study. Using the information from 19 papers (Table 3) and our results, the regression coefficient showed $\mathrm{a} b$ value $=$ $-0.0011, \mathrm{t}=-0.786$, and $\mathrm{P}>0.40$, showing that the frequencies observed are independent of the number of loci analyzed. This is in agreement with several investigators, who think that for an MSI+ pattern to be defined, alterations in just one microsatellite marker may be sufficient. Despite the presence of thousands of microsatellite loci throughout the genome, there is no indication from any
Table 3. Frequencies of microsatellite instability observed in $\mathbf{2 0}$ different studies.

\begin{tabular}{rrrl}
\hline N & X & \multicolumn{1}{c}{ Y } & References \\
\hline 1 & 5 & 0.152 & Wada et al. (5) \\
2 & 12 & 0.000 & Silly et al. (6) \\
3 & 10 & 0.000 & Mori et al. (7) \\
4 & 11 & 0.029 & Robledo et al. (8) \\
5 & 22 & 0.007 & Pabst et al. (9) \\
6 & 69 & 0.004 & Tasaka et al. (10) \\
7 & 14 & 0.002 & Boyer et al. (11) \\
8 & 3 & 0.000 & Rimsza et al. (12) \\
9 & 1 & 0.043 & Indraccolo et al. (21) \\
10 & 8 & 0.523 & Ben-Yehuda et al. (23) \\
11 & 12 & 0.000 & Sill et al. (24) \\
12 & 56 & 0.005 & Baccichet et al. (25) \\
13 & 20 & 0.017 & Fennelly et al. (26) \\
14 & 85 & 0.001 & Takeuchi et al. (27) \\
15 & 5 & 0.010 & Reato et al. (28) \\
16 & 6 & 0.000 & Hayami et al. (29) \\
17 & 16 & 0.016 & Tasaka et al. (30) \\
18 & 11 & 0.250 & Fu et al. (31) \\
19 & 5 & 0.032 & Tanosaki et al. (32) \\
20 & 5 & 0.005 & Present study \\
\hline N $=$ number of the study; X = number of loci \\
studied; Y = frequency of instability observed/ \\
number of reactions performed.
\end{tabular}

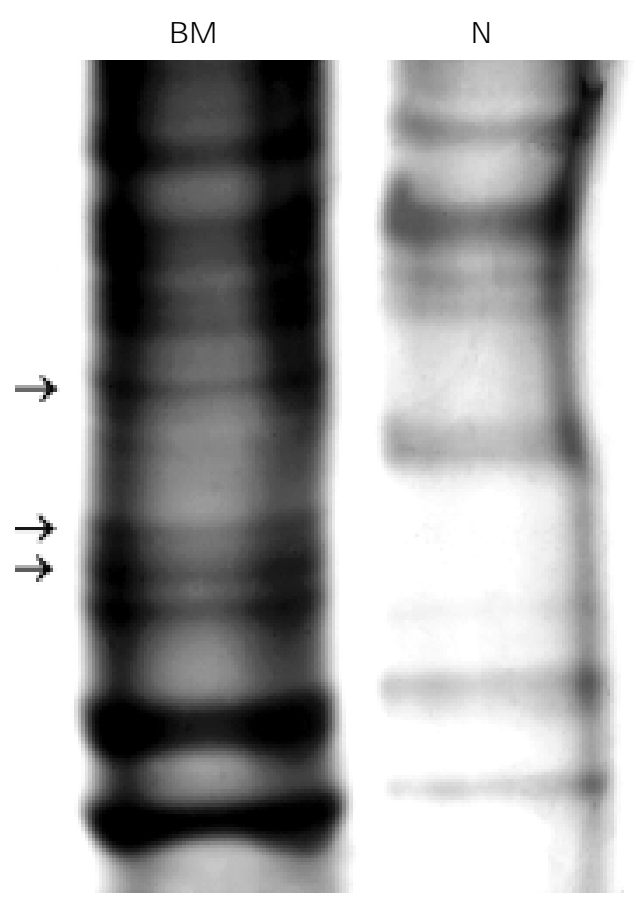

Figure 1. Alterations in the electrophoretic pattern observed in patient number 30, locus SE33. Arrows show shift or extra bands. $\mathrm{BM}=$ bone marrow; $\mathrm{N}=$ normal. 
published report to date that studies based on screening of three microsatellite markers are any less accurate than those using four or more markers (3). Another fact to be considered is the type of marker. Boland et al. (33) defined a panel of five microsatellite markers recommended as a reference for future MSI studies in colorectal cancer. Unfortunately, there is no similar recommendation for leukemias and more data will be necessary to define a basic panel.

With respect to cytogenetic analysis, all the 22 patients with CML in the chronic phase showed the $\mathrm{t}(9 ; 22)$ mutation $(\mathrm{Ph}+)$ and only one had additional chromosome aberrations (number 22). This patient was clinically and hematologically in the chronic phase, but cytogenetic analysis showed trisomy of chromosome 8 and he progressed to blast crisis and died within a short period of time. As expected, additional cytogenetic aberrations were frequently observed in the group of patients with blast crisis. Among the 14 patients with AML several chromosome aberrations were detected, some of them related to the FAB subgroup (Table 2).

Independent of microsatellite analysis, we could establish relations between chro- mosome aberrations and follow-up for most of the patients. For example, in AML, trisomy of chromosome 8 (patient number 32) has been reported to be associated with a low number of complete remissions. The $t(15 ; 17)$ (q22;q12) translocation is related to a high number of remissions with the combination of ATRA and chemotherapy, but the patients are at high risk for early death from intracranial hemorrhage, which was the cause of death of patient number 31. Monosomy 7 (patient number 36$)$ and $\mathrm{t}(9 ; 11)(\mathrm{p} 21-22 ; \mathrm{q} 23)$ (patient number 38) have been reported to be associated with a poor prognosis. These correlations have been extensively described in the literature and are used to guide the choice of the best treatment. Based on these considerations, we conclude that cytogenetics is already the method of choice for prognosis and for treatment indications at the time of diagnosis. For follow-up, molecular cytogenetics and the detection of genic rearrangements by PCR are recognized as better methods than traditional cytogenetics to evaluate minimal residual disease. In contrast, microsatellite analysis does not seem to contribute to the diagnosis or follow-up of leukemic patients.

\section{References}

1. Aaltonen LA, Peltomäki $P$, Leach FS, Sistonen P, Pylkkänen L, Mecklin JP, J ärvinen $\mathrm{H}$, Powell SM, J en J, Hamilton SR, Petersen GM, Kinzler KW, Vogelstein B \& de la Chapelle A (1993). Clues to the pathogenesis of familial colorectal cancer. Science, 260: 812-816.

2. Lothe RA (1997). Microsatellite instability in human solid tumors. Molecular Medicine Today, 3: 61-68.

3. Arzimanoglou II, Gilbert $F \&$ Barber HRK (1998). Microsatellite instability in human solid tumours. Cancer, 82: 1808-1820.

4. Kolodner R (1996). Biochemistry and genetics of eukaryotic mismatch repair. Genes and Development, 19: 1433-1442.

5. Wada C, Shionoya S, Fujino $Y$, Tokuhiro $\mathrm{H}$, Akahoshi $\mathrm{T}$, Uchida $\mathrm{T} \&$ Ohtani $\mathrm{H}$ (1994). Genomic instability of microsatellite repeats and its association with the evolution of chronic myelogenous leuke- mia. Blood, 83: 3449-3456.

6. Silly $\mathrm{H}$, Chase A, Mills Kl, Apfelbeck U, Sormann S, Goldman J M \& Cross NC (1994). No evidence for microsatellite instability or consistent loss of heterozygosity at selected loci in chronic myeloid leukaemia blast crisis. Leukemia, 8: 19231928.

7. Mori N, Takeuchi S, Tasaka T, Spira S, Bem-Yehuda D, Mizoguchi $H$, Schiller G \& Koeffler HP (1997). Absence of microsatellite instability during the progression of chronic myelocytic leukemia. Leukemia, 11: 151-152.

8. Robledo M, Martinez B, Arranz E, Trujillo MJ, Ageitos AG, Rivas C \& Benitez J (1995). Genetic instability of microsatellites in hematological neoplasms. Leukemia, 9: 960-964.

9. Pabst $T$, Schwaller J, Bellomo MJ, Oestreicher $M$, Mühlematter $D$, Tichelli
A, Tobler A \& Fey MF (1996). Frequent clonal loss of heterozygosity but scarcity of microsatellite instability at chromosomal breakpoint cluster region in adult leukemias. Blood, 88: 1026-1034.

10. Tasaka T, Lee S, Spira S, Takeuchi S, Nagai M, Takahara J \& Koeffler P (1997). Microsatellite instability during the progression of acute myelocytic leukaemia. British J oumal of Haematology, 98: 219-221.

11. Boyer J C, Risinger J I \& Farber RA (1998). Stability of microsatellites in myeloid neoplasias. Cancer Genetics and Cytogenetics, 106: 54-61.

12. Rimsza LM, Kopecky KJ, Ruschulte J, Chen IM, Slovak ML, Karanes C, Godwin J , List A \& Willman CL (2000). Microsatellite instability is not a defining genetic feature of acute myeloid leukemogenesis in adults: results of a retrospective study of 132 patients and review of the litera- 
ture. Leukemia, 14: 1044-1051.

13. Bennet J M, Catovski D, Daniel MT, Flandrin G, Galton DAG, Gralnick HR \& Sultan C (1976). Proposals for the classification of the acute leukemias. British J ournal of Haematology, 33: 451-458.

14. Williams DL, Harris A, Williams $\mathrm{KJ}$, Brosius MJ \& Lemonds W (1984). A direct bone marrow chromosome technique for acute lymphoblastic leukemia. Cancer Genetics and Cytogenetics, 13: 239-257.

15. Scheres VMJC (1972). Identification of two Robertsonian translocations with a Giemsa banding technique. Human Genetics, 15: 253-256.

16. Mitelman F (1995). An International System for Human Cytogenetic Nomenclature (ISCN). S. Karger, Basel, Switzerland.

17. Sinnet $D$, Lavergne $L$, Melançon SB, Dallaire L, Potier M \& Labuda D (1988). Lesch-Nyhan syndrome: molecular investigation of three French Canadian families using HPRT CDNA probe. Human Genetics, 81: 4-8.

18. Sajantila A \& Lukka M (1993). Improved separation of PCR amplified VNTR alleles by a vertical polyacrylamide gel electrophoresis. International J ournal of Legal Medicine, 105: 355-359.

19. Budowle B, Chakraborty R, Giusti AM, Eisenberg AJ \& Allen R (1991). Analysis of the VNTR locus D1S80 by the PCR followed by high-resolution PAGE. American J ournal of Human Genetics, 48: 137144.

20. The genome database (GDB): http:// gdbwww.gdb.org. Accessed April, 1998.

21. Indraccolo S, Simon M, Hehlmann R, Erfle V, Chieco-Bianchi L \& Leib-Moesch C (1995). Genetic instability of a dinucle- otide repeat-rich region in three hematologic malignancies. Leukemia, 9: 15171522.

22. Indraccolo S, Minuzzo S, Nicoletti L, Cretella E, Simon M, Papakonstantinou G, Hehlmann R, Mion M, Bertorelle R, Roganovic J \& Chieco-Bianchi L (1999). Mutator phenotype in human hematopoietic neoplasms and its association with deletions disabling DNA repair genes and bcl-2 rearrangements. Blood, 94: 24242432.

23. Ben-Yehuda D, Krichevsky S, Caspi $O$, Rund D, Polliack A, Abeliovich D, Zelig O, Yahalom V, Paltiel O, Or R, Peretz T, BemNeriah S, Yehuda O \& Rachmilewitz EA (1996). Microsatellite instability and p53 mutations in therapy-related leukemia suggest mutator phenotype. Blood, 88: 4296-4303.

24. Sill H, Goldman J M \& Cross NC (1996). Rarity of microsatellite alterations in acute myeloid leukaemia. British J ournal of Cancer, 74: 255-257.

25. Baccichet A, Benachenhou N, Couture F, Leclerc J -M \& Sinnet D (1997). Microsatellite instability in childhood $T$ cell acute lymphoblastic leukemia. Leukemia, 11: 797-802.

26. Fennelly J, Wright E \& Plumb M (1997). Mini- and microsatellite mutations in radiation-induced acute myeloid leukaemia in the CBA/H mouse. Leukemia, 11: 807810.

27. Takeuchi S, Seriu T, Tasaka T, Koike M, Cho SK, Park S, Slater J , M ufti I, Hatta Y, Miyoshi I, Bartram CR \& Koeffler P (1997). Microsatellite instability and other molecular abnormalities in childhood acute lymphoblastic leukaemia. British J ournal of Haematology, 98: 134-139.
28. Reato G, Basso G, Putti MC, Cignetti A, Guarini A \& Foa R (1998). Microsatellite analysis in childhood acute lymphoblastic leukemia. Haematologica, 83: 403-407.

29. Hayami $Y$, Komatsu $H$, lida S, Utsunomiya A, Hanada S, Hua XJ , Huiping N, Harada S, Tsuboi K, Wakita A, Kato T \& Ueda R (1999). Microsatellite instability as a potential marker for poor prognosis in adult T cell leukemia/lymphoma. Leukemia and Lymphoma, 32: 345-349.

30. Tasaka T, Lee S, Spira S, Takeuchi S, Hatta Y, Nagai M, Takahara J \& Koeffler HP (1996). Infrequent microsatellite instability during the evolution of myelodisplastic syndrome to acute myelocytic leukemia. Leukemia Research, 20: 113-117.

31. Fu $Y$, Zhu $P$, Wang $W$, Liu $Y \&$ Xue $H$ (1998). The microsatellite instability and loss of heterozygosity in chromosome translocation breakpoint in leukemia. Zhonghua Yixue Yichuanxue Zazhi, 15: 271-273.

32. Tanosaki S, Inokuchi K, Shimada T \& Dan K (1998). Relation between microsatellite instability and $\mathrm{N}$-ras mutation and duration of disease free survival in patients with acute leukemia. Cancer, 83: 475-481.

33. Boland CR, Thibodeau SN, Hamilton SR, Sidransky D, Eshleman J R, Burt RW, Meltzer SJ, Rodriguez-Bigas MA, Fodde R, Ranzani GN \& Srivastava S (1998). A National Cancer Institute Workshop on microsatellite instability for cancer detection and familial predisposition: development of international criteria for the determination of microsatellite instability in colorectal cancer. Cancer Research, 58: 5248-5257. 